\title{
Worry, Anxiety and Stress
}

\author{
*Adriano Santacaterina \\ Department of Psychoterapist, Italy
}

Submission: July 06, 2017; Published: July 26, 2017

*Corresponding author: Adriano Santacaterina, Department of Psychoterapist, Italy; Tel: 3331028068; Email: santacate@virgilio.it

\section{Short Communication}

Everybody worries sometime and some people worry all the time. The question is how to worry well.

What is worry, how do we do it, what is the purpose of it, is it possible that worry has a positive function?

Worry basically is an adaptive function, it's something that allow us to go over and over on our mind in an attempt to solve a problem or to get over a situation. In this respect it is adaptive and all we humans are born with faculties in our brain that as far as we know don't belong to any other creature on earth. That has allowed us to become from a vulnerable prayed animal to the dominant creature on earth.

We don't have many tools for survival, if you look at a human as an animal we are pretty vulnerable. We don't run very fast, we don't have big teeth, we don't have big jaws, we can swim a little bit but not very much. So without our technology in the African savannah we are basically meat.

We have systems built in within our systems that we inherited from the development of other preyed animals that lead to things like the fight or flight response. These systems are adaptive in some situation and maladaptive in some other.

One of the faculty that we developed as our ability to function is our imagination. Imagination is the key faculty that separates the humans from any other form of life.

Imagination let us remember things from the past, it let us project things into the future and also think about how things would be if you did something in this way or in that way. Everything that exist in earth that wasn't made by God or by Nature, everything that the human kind made, started in somebody's imagination. So outside God or Nature, human imagination is the most powerful force in the earth and the thing is that few of us has been basically taught how to use it. Most of our education is regarding how to use other mental faculties as the ability to analyze, the ability to calculate and the linear logical scientific way of thinking that have also contributed to make our specie very powerful.

A lot starts from the imagination, and worry is a function of the imagination. If you didn't have an imagination you couldn't be worried. That's what lobotomies are about, and that's what certain medications are about.

Worrying well or worrying more effectively has to do on how you use your imagination. Worry and stress have a good deal of overlap as well as anxiety. They are all a bit different but they all overlap and they share in a lot of different time and ways.

Our consciousness and the ability to become conscious is potentially the greatest tool that we have for improving our lives. If we don't know how to use it is something that can make our life miserable. So if you want to do something you must learn how to use these capacities. There is no going back. Sometimes we try to go back with other ways of managing stress and anxiety by drinking too much or taking drugs, by taking medications or by eating too much: all the billions of ways we have for going unconscious.

\section{How Worry, Stress and Anxiety differ?}

Worry is a type of thinking, it is letting your thoughts going to the worse of scenarios It is letting yourself to be entranced and hypnotized by your problems. The most common use of our imagination is to worry ourselves sick. It is a repetitive kind of thinking often troubled about the future or the past: rumination.

Rumination often has to do with things that are either in the past or in the future, it's the opposite of being here and now.

The adaptive aspect of rumination is that it is an attempt by nature to resolve a problem or to avoid threats. The advantage of having a problem going over and over in our mind is similar of when you have a big tangle of yarn or thread and you try to untangle it by finding a place where it is lose. You pull it for a while. You get some loseness and then again some stuck and 
you turn the tangled yarn over until you find another lose place and you free up some more stuff. You turn it over again and you free up some more stuff. You keep doing that, looking at it from different angles, finding some more lose places, finding more things that are knotted together. If you persevere with it more often than not you are going to get the thing untangled.

I think that is the function of worry, it makes our concerns transportable so you can think about it at anytime. That can be an advantage or a disadvantage, it depends on whether you are using your brain or you are being wronged by it. At least in certain circumstances your mind can learn to use your brain in better ways.

It's very easy for this adaptive function capable of turning things over and over to become a habit or to become repetitive or ruminative. There is a reason for that, there is a couple of magical functions of worry. The first one is that most things that you worry about never happen. So comes out a belief that the things did not happen because you worried about them. The second is that sometimes worrying about things distract us from other matters that actually bother us and that is too hard for us to take. So it is useful to keep the mind very busy as a way to quiet our emotions and to prevent them to come up because emotions are hard to feel.

Anxiety is an uncomfortable feeling, often in the gut or chest, of fear, apprehension or dread. Dread is the feeling that makes you think: «Oh my God something bad is going to happen». It may be attached to something or maybe it can be free floating and not attached to anything. Often exhibits physical symptoms like rapid heart rate, pain in the chest, sweating or shortness of breath.

In panic attacks the feeling is of an impending doom, people with panic attacks feel that they're going to die. The symptoms are often in the chest or in the abdomen. Anxiety is a function of the limbic system or of the emotional part of the brain. So while worry belongs to the thinking part of the brain (the cortex), anxiety typically comes from the emotional part of the brain.

Stress is an actual and physical response to a threat, really or imagined. In modern life most of the threats are either perceived or imagined. The problem is that the fight or flight response can go off in answer to threats that are not predators. That it can go off in response to stock market movements, to economic changes, to thinking about aging, to thinking about whether you can meet your responsibilities. All kinds of stuff that unless you know where the button off is, like in you television set, in your radio or in your computer, you end up pumping into your brain in a $24 / 7$ all the bad news or every bad thing that is happening around the world to anybody. And there is a balance yet again between been able to predict the future, take measures to prevent things to happen that don't need to happen and freaking out for months about something that probably will never happen.

Stress is a physical response it is not stuff that it is happening to you. It's a response that causes blood flow to the largest muscles not to periphery. It heightens senses, it increases heart rates and blood pressure as well as causes an adrenalin surge. All that it is needed to survive a short term tension like the fight \& flight response when facing a bear in the forest. After a while the stress finishes and you've burned all the chemicals you produced. If you survive you can go back to your community telling everybody the story of how you run away or how you killed the bear. Your body rests compensating and recharging itself by replacing all the chemicals you've produced during that very intensive but short period of time. In a way or in another all will be over in twenty or thirty minutes. There is none in this of the years of stress that you can experiment every morning worrying about one thing or another. Not only in the daylight but in nights as well. All that takes your resilience away and becomes a very vicious cycle. In the end to review: Worry is a repetitive and circular thinking (rumination); Anxiety is an uncomfortable feeling or fear or dread; Stress is a physical survival response (fight or flight).

\section{Your next submission with Juniper Publishers} will reach you the below assets

- Quality Editorial service

- Swift Peer Review

- Reprints availability

- E-prints Service

- Manuscript Podcast for convenient understanding

- Global attainment for your research

- Manuscript accessibility in different formats ( Pdf, E-pub, Full Text, Audio)

- Unceasing customer service

Track the below URL for one-step submission https://juniperpublishers.com/online-submission.php 